\title{
Introductory Business Textbook Revision Cycles: Are They Getting Shorter?
}

Brian Zinser, Lake Superior State University, USA

Gary Brunswick, Northern Michigan University, USA

\begin{abstract}
The rate of textbook revision cycles is examined in light of the recent trend towards more rapid revisions (and adoptions of textbooks). The authors conduct background research to better understand the context for textbook revision cycles and the environmental forces that have been influencing what appears to be more rapid textbook revisions. A study methodology is designed, data are collected and analyzed, and the results are reported, eventually supporting the contention that textbook revision cycles are indeed becoming more frequent. The managerial implications of the findings are discussed, along with future areas for research.
\end{abstract}

Keywords: business textbook revision cycles

\section{INTRODUCTION}

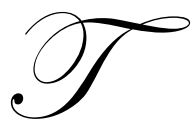

he cost of an undergraduate college education in North America continues to escalate. While most of the rhetoric on increasing costs is focused on rising tuition and fees, the cost of college textbooks is often part of the conversation. Mui and Kinzie (2008) estimate that a typical undergraduate's textbook costs range from $\$ 700$ to $\$ 1,100$ per academic year.

A market for used textbooks has always existed as books are essentially a durable good. The target market's adoption of the World Wide Web in the 1990s and the corresponding development of e-commerce, including online retailers, auction sites and cybermediaries has made the used textbook market more dynamic and efficient (Koch, 2006). In most durable goods industries, producers of new products end up competing against the used market of their products. However, in the collegiate textbook market, publishers function as a durable goods monopolist (Iizuka, 2007). They have the ability to eliminate competition from used books through the use of a product management strategy known as planned obsolescence. Iizuka's empirical analysis of the collegiate textbook industry found that publishers have a tendency to accelerate revisions when competition from the used book marketplace increases. Additionally, Koch (2006) notes that publishers tend to accelerate revisions to textbooks that sell well and release "new editions."

One area in which the authors have found no empirical studies is whether revision cycles of introductory business textbooks; i.e., accounting, economics, finance, management, marketing, and business statistics, have shortened since the emergence of the World Wide Web. Using data collected from the Faculty Center Network (http://www.facultycenter.net/) and its MBS Textbook Exchange, Inc. database, this brief study attempts to establish if there is enough evidence to support the claim that introductory business textbook revision cycles during the last decade were shorter than revision cycles prior to 2000, when the market for used collegiate textbooks could arguably be considered less efficient sans the World Wide Web.

\section{LITERATURE REVIEW}

\section{Durable Goods Monopolist and the Collegiate Textbook Market}

Iizuka (2007) identified two product management strategies a durable goods monopolist could use to reduce potential competition from used goods, reduce durability, or "kill off" used goods. Durability is probably not 
a product attribute that can be easily engineered by book publishers. Because of the relatively rare market structure of the collegiate textbook industry, a publisher can "kill off" used books through planned obsolescence. Some authors, including Swan (1980), have argued that a new product's price includes all future transactions and theoretically used products do not compete with new products. Others, including Benjamin and Kormendi (1974) and Miller (1974), have found that under certain scenarios, a monopolist can increase profits by eliminating the used goods market. Miller specifically examined the textbook market.

The textbook industry distribution channel consists of the publishers, distributors or wholesalers, and college bookstores. The market of publishers is oligopolistic as five companies sell about $80 \%$ of all new college textbooks. The market for wholesaling and distributing books is also oligopolistic as four firms dominate the market. Furthermore, these four firms also own or operate more than 1,500, or approximately $35 \%$, of all college bookstores and are very active in the used book market as profit margins tend to be higher for selling used books versus new books (Koch, 2006). Internet sales of books and course materials have been on the rise too. A 2008 Student Watch research report (NACS overview of Higher Education Opportunity Act Textbook Provisions, 2009) indicated that $24 \%$ of students reported purchasing books and materials online, often times from college bookstore sites.

The Advisory Committee on Student Financial Assistance (2007) argues that the "market for textbooks and learning resources is broken" (p.9). Although students pay for and are the end users of textbooks, they have no direct control over the price, format, or quality of the product. Textbooks are selected by faculty members or faculty committees and bookstores simply order them. Because of the relatively rare market structure of the textbook industry in the United States, textbook prices tend to be inelastic. The market structure closely resembles that of the prescription drug industry (Carbaugh \& Ghosh, 2005).

Although there appears to be agreement among most stakeholders that the costs of college textbooks is out of control and that the economics of college textbook marketing is complex, there tends to be little agreement as to what is the primary cause of the problem. Several possible explanations appear in the literature, including higher development costs of textbooks and ancillary instructional support materials, bundling of textbooks and supplementary materials, and the increased frequency in revisions and new editions (Government Accountability Office, 2005; Iizuka, 2007; Koch, 2006; Student Public Interest Research Groups, 2007).

\section{Collegiate Textbook Revision Cycles}

According to the General Accountability Office (2005), industry representatives and public interest groups have suggested, and publishers have agreed, that the revision cycles have shortened over the last ten years. Ten to twenty years ago, revision cycles were every four to five years; three to four years is now more typical. Furthermore, introductory-level classes have shorter revision cycles than other books because the supply of used books is greater in these types of courses due to the sheer number of books in circulation and the fact that students are more likely to sell introductory books back to bookstores and buyers. Koch (2006) notes that unit sales of new textbooks is highest in the first year or two of publication and then tend to fall off as used books begin to become available. New textbook prices are reported to be as much as 58\% higher than used textbooks and students' net cost of a book includes their ability to sell back the book at the end of the semester (California Public Interest Research Group, 2004).

The California Public Interest Research Group (2004) found that more than three-quarters (76\%) of all faculty surveyed estimated the new editions were justified half of the time or less. More than $40 \%$ of faculty surveyed said that new textbooks were "rarely" or "never" justified. The State Public Interest Research Groups Higher Education Project (2005) reported similar results, noting that more than two-thirds (71\%) felt new editions are justified only "sometimes" or "rarely." To the contrary, the Association of American Publishers (Why PIRG is Wrong) commissioned a poll of 1,029 college professors that reported $80 \%$ responded that they think it is important that textbooks be as current as possible.

In 2006, the U.S. House Committee on Education and Labor members P. "Buck" McKeon and David Wu requested the Advisory Committee on Student Financial Assistance to further study the textbook industry and report 
back to Congress (Advisory Committee on Student Financial Assistance, 2007). A resulting textbook section was added to the Higher Education Opportunity Act of 2008. Among its major provisions is a requirement for publishers to provide faculty with 1) the copyright dates of the three previous editions and 2) an account of the substantial content revisions of the newest edition (NACS Overview of Higher Education Opportunity Act Textbook Provisions, 2009). The new regulations take effect July 2010.

Previous studies and antidotal claims by both student advocacy groups and publishers have laid the contextual groundwork for further study of textbook revision cycles, particularly in the area of "introductory" or "principles" business textbooks where one could argue that the rate of change of substantive content is relatively slow.

\section{METHOD}

\section{Research Design}

To test the hypothesis that revision cycles of introductory business textbooks have become shorter in the last decade, a paired difference experiment was used to test the differences in the means of revision cycles of widely adopted textbooks. The year 2000 was used as the pivotal differential treatment year to represent the effect of the World Wide Web on the used textbook market. A sample of 26 introductory business textbooks ( 3 accounting, 5 economics, 3 finance, 5 management, 7 marketing, and 3 business statistics) was composed and is presented in Table 1. Since the sample size was less than 30 , the authors assumed that the population of the paired differences is normally distributed.

\section{Sample And Data Collection}

The authors used the Faculty Center Network's (http://www.facultycenter.net/) subject ranking and adoption occurrence information of introductory business textbooks in the following subject areas: accounting, economics, finance, management, marketing, and business statistics. The information, which provides a means of comparison and evaluation of a textbook's demand and popularity, is compiled from nearly three decades of data collected by MBS Textbook Exchange, Inc. MBS Textbook Exchange is a major textbook wholesaler and has gathered the ordering and textbook adoption data from ordering history of approximately 3,600 active college bookstore accounts in North America.

Using MBS Textbook Exchange's unique subject taxonomy, introductory textbooks in each subject area, with the exception of finance and business statistics, were selected from subject subcategories which were labeled "principles." For finance, textbooks were selected from both the principles of corporate finance and managerial finance subcategories, with those selected from the later subcategory having the word either "essentials" or "principles" in the textbook's title. The statistics and probability for business category contained no subcategories and textbooks that were selected were assumed to be introductory textbooks based on their titles.

In order to include only popular, or widely adopted, introductory textbooks in the sample, the Faculty Center Network's subject ranking was used and only books that had a rating of 3 or higher were selected. Books with a rating of 3 or higher are in or above the top 87 percentile in terms of demand. Finally, only textbooks which had a minimum of 10 editions were included in the sample in order to have an adequate history of revision cycles, both before and after the differential treatment year 2000.

\section{Special Procedure for Calculating Mean Differences}

The revision years were found for each edition of each textbook. The mean differences between revision years were calculated with the point of differential treatment being the year 2000. In the case that the textbook was not revised in 2000, the authors used the difference between the first revision after 2000 and the last revision before 2000 in the calculation of the mean revision cycle, in years, prior to 2000 and vice versa. The resulting means in years, of revision cycles both pre-2000 and post-2000 that were used to conduct the paired differences test, are shown in Table 2. 
Table 1: Introductory Business Textbooks

\begin{tabular}{|c|c|c|c|c|}
\hline Subject & Title & Authors(s) & Publisher & Edition/Year \\
\hline Accounting & Accounting & $\begin{array}{l}\text { Warren, Carl } \\
\text { Reeve, James } \\
\text { Duchac, Jonathan }\end{array}$ & $\begin{array}{l}\text { South Western/ } \\
\text { Cengage }\end{array}$ & $23^{\text {rd }} / 2009$ \\
\hline Accounting & Fundamental Accounting Principles & $\begin{array}{l}\text { Wild, John J. } \\
\text { Chiappetta, Barbara } \\
\text { Larson, Kermit D. }\end{array}$ & McGraw Hill & $19^{\text {th }} / 2009$ \\
\hline Accounting & Principles of Accounting & $\begin{array}{l}\text { Needles, Belverd E. } \\
\text { Powers, Marian } \\
\text { Crosson, Susan V. }\end{array}$ & $\begin{array}{l}\text { South Western/ } \\
\text { Cengage }\end{array}$ & $11^{\text {th }} / 2011$ \\
\hline Economics & Economics & $\begin{array}{l}\text { McConnell, Campbell R. } \\
\text { Brue, Stanley L. } \\
\text { Flynn, Sean M. }\end{array}$ & McGraw Hill & $18^{\text {th }} / 2009$ \\
\hline Economics & Economics : Private and Public Choice & $\begin{array}{l}\text { Gwartney, James } \\
\text { Stroup, Richard } \\
\text { Macpherson, David } \\
\text { Sobel, Russell S. }\end{array}$ & $\begin{array}{l}\text { South Western/ } \\
\text { Cengage }\end{array}$ & $13^{\text {th }} / 2011$ \\
\hline Economics & Economics Today & Miller, Roger & $\begin{array}{l}\text { Pearson/ } \\
\text { Prentice Hall }\end{array}$ & $15^{\text {th }} / 2010$ \\
\hline Economics & Economy Today & Schiller, Bradley R. & McGraw Hill & $12^{\text {th }} / 2010$ \\
\hline Economics & Making of Economic Society & $\begin{array}{l}\text { Heilbroner, Robert } \\
\text { Milberg, William }\end{array}$ & $\begin{array}{l}\text { Pearson/ } \\
\text { Prentice Hall }\end{array}$ & $12^{\text {th }} / 2007$ \\
\hline Finance & Principles of Corporate Finance & $\begin{array}{l}\text { Brealey, Richard A. } \\
\text { Myers, Stewart } \\
\text { Allen, F. }\end{array}$ & McGraw Hill & $10^{\text {th }} / 2011$ \\
\hline Finance & Essentials of Managerial Finance & $\begin{array}{l}\text { Besley, Scott } \\
\text { Brigham, E }\end{array}$ & $\begin{array}{l}\text { South Western/ } \\
\text { Cengage }\end{array}$ & $14^{\text {th }} / 2008$ \\
\hline Finance & Principles of Managerial Finance & Gitman, Lawrence J. & $\begin{array}{l}\text { Pearson/ } \\
\text { Prentice Hall }\end{array}$ & $12^{\text {th }} / 2009$ \\
\hline Management & Management & Griffin, Ricky W. & $\begin{array}{l}\text { South Western/ } \\
\text { Cengage }\end{array}$ & $10^{\text {th }} / 2011$ \\
\hline Management & Management & $\begin{array}{l}\text { Rue, Leslie W. } \\
\text { Byars, Lloyd L. }\end{array}$ & McGraw Hill & $13^{\text {th }} / 2009$ \\
\hline Management & Management & Schermerhorn, John R. & Wiley & $10^{\text {th }} / 2010$ \\
\hline Management & Management & $\begin{array}{l}\text { Robbins, Stephen P. } \\
\text { Coulter, Mary }\end{array}$ & $\begin{array}{l}\text { Pearson/ } \\
\text { Prentice Hall }\end{array}$ & $10^{\text {th }} / 2009$ \\
\hline Management & Modern Management & $\begin{array}{l}\text { Certo, Samuel C. } \\
\text { Certo, S. Trevis }\end{array}$ & $\begin{array}{l}\text { Pearson/ } \\
\text { Prentice Hall }\end{array}$ & $11^{\text {th }} / 2009$ \\
\hline Marketing & Basic Marketing & $\begin{array}{l}\text { Perreault, William D. } \\
\text { McCarthy, E. Jerome } \\
\text { Cannon, Joseph P. }\end{array}$ & McGraw Hill & $17^{\text {th }} / 2009$ \\
\hline Marketing & Contemporary Marketing & $\begin{array}{l}\text { Boone, Louis E. } \\
\text { Kurtz, David L. }\end{array}$ & $\begin{array}{l}\text { South Western/ } \\
\text { Cengage }\end{array}$ & $14^{\text {th }} / 2011$ \\
\hline Marketing & Essentials of Marketing & $\begin{array}{l}\text { Perreault, William D. } \\
\text { McCarthy, E. Jerome } \\
\text { Cannon, Joseph P. }\end{array}$ & McGraw Hill & $12^{\text {th }} / 2010$ \\
\hline Marketing & Marketing & $\begin{array}{l}\text { Lamb, Charles W. } \\
\text { Hair, Joseph F. } \\
\text { McDaniel, Carl }\end{array}$ & $\begin{array}{l}\text { South Western/ } \\
\text { Cengage }\end{array}$ & $11^{\text {th }} / 2011$ \\
\hline Marketing & Marketing) & $\begin{array}{l}\text { Pride, William M. } \\
\text { Ferrell, O.C. }\end{array}$ & $\begin{array}{l}\text { South Western/ } \\
\text { Cengage }\end{array}$ & $15^{\text {th }} / 2010$ \\
\hline Marketing & Marketing & $\begin{array}{l}\text { Etzel, Michael J. } \\
\text { Walker, Bruce J. } \\
\text { Stanton, William J. }\end{array}$ & McGraw Hill & $14^{\text {th }} / 2009$ \\
\hline Marketing & Principles of Marketing & $\begin{array}{l}\text { Kotler, Philip } \\
\text { Armstrong, Gary }\end{array}$ & $\begin{array}{l}\text { Pearson/ } \\
\text { Prentice Hall }\end{array}$ & $13^{\text {th }} / 2010$ \\
\hline Statistics & $\begin{array}{l}\text { Statistical Techniques in Business and } \\
\text { Economics }\end{array}$ & $\begin{array}{l}\text { Lind, Douglas A. } \\
\text { Marchal, William G } \\
\text { Wathen, Samuel A. }\end{array}$ & McGraw Hill & $14^{\text {th }} / 2010$ \\
\hline Statistics & Statistics for Business and Economics & $\begin{array}{l}\text { Anderson, David R. } \\
\text { Sweeney, Dennis T. } \\
\text { Williams, Thomas A. }\end{array}$ & $\begin{array}{l}\text { South Western/ } \\
\text { Cengage }\end{array}$ & $11^{\text {th }} / 2010$ \\
\hline Statistics & Statistics for Business and Economics & $\begin{array}{l}\text { McClave, James } \\
\text { Benson, P. George } \\
\text { Sincich, Terry }\end{array}$ & $\begin{array}{l}\text { Pearson/ } \\
\text { Prentice Hall }\end{array}$ & $11^{\text {th }} / 2011$ \\
\hline
\end{tabular}


Table 2: Means, in Years, of Introductory Business Textbook Revision Cycles

\begin{tabular}{|c|c|c|c|}
\hline 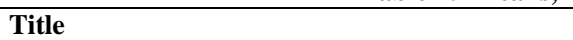 & Authors(s) & Pre 2000 & Post 2000 \\
\hline Accounting & $\begin{array}{l}\text { Warren, Carl } \\
\text { Reeve, James } \\
\text { Duchac, Jonathan }\end{array}$ & 3.53 & 2.60 \\
\hline Fundamental Accounting Principles & $\begin{array}{l}\text { Wild, John J. } \\
\text { Chiappetta, Barbara } \\
\text { Larson, Kermit D. }\end{array}$ & 3.13 & 2.60 \\
\hline Principles of Accounting & $\begin{array}{l}\text { Needles, Belverd E. } \\
\text { Powers, Marian } \\
\text { Crosson, Susan V. }\end{array}$ & 3.00 & 3.00 \\
\hline Economics & $\begin{array}{l}\text { McConnell, Campbell R. } \\
\text { Brue, Stanley L. } \\
\text { Flynn, Sean M. }\end{array}$ & 3.00 & 2.60 \\
\hline Economics : Private and Public Choice & $\begin{array}{l}\text { Gwartney, James } \\
\text { Stroup, Richard } \\
\text { Macpherson, David } \\
\text { Sobel, Russell S. }\end{array}$ & 3.00 & 2.80 \\
\hline Economics Today & Miller, Roger & 2.80 & 2.17 \\
\hline Economy Today & Schiller, Bradley R. & 2.86 & 2.60 \\
\hline Making of Economic Society & $\begin{array}{l}\text { Heilbroner, Robert } \\
\text { Milberg, William }\end{array}$ & 4.00 & 4.67 \\
\hline Principles of Corporate Finance & $\begin{array}{l}\text { Brealey, Richard A. } \\
\text { Myers, Stewart } \\
\text { Allen, F. }\end{array}$ & 3.80 & 2.80 \\
\hline Essentials of Managerial Finance & $\begin{array}{l}\text { Besley, Scott } \\
\text { Brigham, E }\end{array}$ & 2.91 & 4.00 \\
\hline Principles of Managerial Finance & Gitman, Lawrence J. & 3.00 & 3.00 \\
\hline Management & Griffin, Ricky W. & 3.00 & 3.00 \\
\hline Management & $\begin{array}{l}\text { Rue, Leslie W. } \\
\text { Byars, Lloyd L. }\end{array}$ & 2.88 & 2.40 \\
\hline Management & Schermerhorn, John R. & 3.00 & 2.80 \\
\hline Management & $\begin{array}{l}\text { Robbins, Stephen P. } \\
\text { Coulter, Mary }\end{array}$ & 3.00 & 2.60 \\
\hline Modern Management & $\begin{array}{l}\text { Certo, Samuel C. } \\
\text { Certo, S. Trevis }\end{array}$ & 2.86 & 3.00 \\
\hline Basic Marketing & $\begin{array}{l}\text { Perreault, William D. } \\
\text { McCarthy, E. Jerome } \\
\text { Cannon, Joseph P. }\end{array}$ & 3.23 & 2.60 \\
\hline Contemporary Marketing & $\begin{array}{l}\text { Boone, Louis E. } \\
\text { Kurtz, David L. }\end{array}$ & 3.00 & 2.67 \\
\hline Essentials of Marketing & $\begin{array}{l}\text { Perreault, William D. } \\
\text { McCarthy, E. Jerome } \\
\text { Cannon, Joseph P. }\end{array}$ & 3.00 & 2.60 \\
\hline Marketing & $\begin{array}{l}\text { Lamb, Charles W. } \\
\text { Hair, Joseph F. } \\
\text { McDaniel, Carl }\end{array}$ & 2.00 & 1.86 \\
\hline Marketing) & $\begin{array}{l}\text { Pride, William M. } \\
\text { Ferrell, O.C. }\end{array}$ & 2.30 & 2.60 \\
\hline Marketing & $\begin{array}{l}\text { Etzel, Michael J. } \\
\text { Walker, Bruce J. } \\
\text { Stanton, William J. }\end{array}$ & 3.36 & 3.25 \\
\hline Principles of Marketing & $\begin{array}{l}\text { Kotler, Philip } \\
\text { Armstrong, Gary }\end{array}$ & 2.63 & 2.33 \\
\hline Statistical Techniques in Business and Economics & $\begin{array}{l}\text { Lind, Douglas A. } \\
\text { Marchal, William G } \\
\text { Wathen, Samuel A. }\end{array}$ & 3.50 & 2.80 \\
\hline Statistics for Business and Economics & $\begin{array}{l}\text { Anderson, David R. } \\
\text { Sweeney, Dennis T. } \\
\text { Williams, Thomas A. }\end{array}$ & 3.00 & 2.80 \\
\hline Statistics for Business and Economics & $\begin{array}{l}\text { McClave, James } \\
\text { Benson, P. George } \\
\text { Sincich, Terry }\end{array}$ & 3.29 & 3.40 \\
\hline
\end{tabular}




\section{RESULTS / DISCUSSION AND MANAGERIAL IMPLICATIONS}

An analysis of the results of a paired difference $t$ test, comparing the sample of introductory business textbook's mean revision cycles prior to 2000 versus after 2000, found that there was a mathematical difference in the means (with standard deviations in parentheses), 3.04(0.41) versus 2.83(0.55) years, respectively, resulting in a mean difference of $0.21(.45)$. The mean difference was statistically significant, $t(25)=2.39, p=.012$. The difference in the standard deviations of the means of the revision cycles suggests that revision cycles were more consistent prior to 2000 .

The results of this study indicate that there is strong evidence to support the hypothesis that revision cycles of introductory business textbooks have shortened during the last ten years and should be further studied. Of interest would be causal studies to determine if the shortening of the cycles is a result of improved efficiencies in the used textbook market as a result of the target markets adoption of the World Wide Web and subsequent development of e-commerce.

A range of potentially significant key factors influencing shorter revision cycles would seem to exist. For example, given rapidly changing nature of technology and media exposure habits on the part of consumer, examples found in introductory marketing textbooks become quickly time-dated, although some textbook authors have attempted to use monthly or quarterly updates to make the supplemental materials for textbooks appear to be more "real time". Clearly, there has been pressure on textbook publishers to reign in prices and/or price increases for textbooks. In several states and at the federal level, legislators have convened hearings in an attempt to better understand and potentially influence textbook pricing. All of this would seem to favor longer revision cycles, not shorter ones.

Another interesting development has been in the area of "no frills" versions of textbooks. Publishers, such as Atomic Dog and 4LTR Press, have specialized in developing and introducing shorter soft-cover (and e-book) versions of basic textbooks for most areas in business and even a few textbooks targeted at specialized courses, such as international business, money and banking, and consumer behavior. The implied strategy on the part of these textbooks publishers seems to be to focus on a lower price point, which would lessen the perceived cost(s) associated with more frequent textbook revisions and adoptions (i.e., students will appreciate a lower cost textbook, regardless of how frequently the book is revised).

The advent of e-readers and textbooks in the form of e-books also seems to hold an interesting range of managerial implications. E-books would seem to be the lowest cost version of delivering textbook content to students and would also allow for the most potential in terms of updates. In theory, a textbook in e-book form could be updated at virtually any time, which may not be desirable from both a faculty member's viewpoint as well as a student's viewpoint (i.e., perhaps beginning of semester updates would be the most frequent). Will textbook publishers partner with Amazon or Sony and package (or give away, free) e-readers with the purchase of one or more textbooks? Will colleges and universities provide students with free e-readers in an attempt to drive down the cost of textbook usage? What are the inherent advantages and disadvantages of textbook content delivered in hard copy form vs. in e-book form (i.e., will e-books positively or negatively influence learning for some/many/all students)? It would seem that given current trends, there is considerable inertia behind e-readers and e-books and the next several years should yield some clues as to these types of questions.

\section{FUTURE RESEARCH}

The authors suggest that future studies could include improved research design, including reproducing the study with a larger, more comprehensive sample of introductory business textbooks, including both hard copy and ebook forms of texts. Although not a causality study, challenges to the assumptions used in this study, particularly the use of the year 2000 as the pivotal differential treatment point to represent the advent of e-commerce in the used textbook market, needs to be further studied. Finally, several areas of related study, which could be of value to various stakeholders of the collegiate business textbook publishing industry, include the market's need for frequently revised textbooks, what constitutes substantive changes in content and publisher's cause for revising textbooks more frequently. 


\section{AUTHOR INFORMATION}

Brian Zinser has been an assistant professor of marketing in the School of Business at Lake Superior State University since 2005. He has nearly twenty years of professional experience in marketing management positions in the financial services industry as well as served for more than five years as director of marketing for Northern Michigan University. Zinser received an A.B. from the University of Illinois at Urbana-Champaign and a M.M. from the J.L. Kellogg Graduate School of Management at Northwestern University. He is currently pursuing his D.B.A. in marketing from the Falls School of Business at Anderson University (Indiana).

Gary J. Brunswick holds a Ph.D. in Business Administration from Arizona State University, and currently hold the rank of Professor of Marketing at Northern Michigan University. His research interests include marketing strategy, services marketing and e-commerce. His research has been published in range of journals including, Journal of the Academy of Marketing Science, Journal of Consumer Behaviour, The Marketing Management Journal, The Journal of Professional Services Marketing, The International Journal of Case Studies and Research, The Journal of the International Academy of Case Studies, The Academy of Educational Leadership Journal and The Academy of Marketing Studies Journal.

\section{REFERENCES}

1. Advisory Committee on Student Financial Assistance. (2007). Turning the page: Making college textbooks more affordable. Washington, DC: U.S. Department of Education.

2. Benjamin, D., \& Kormendi, R. (1974). The interrelationship between markets for new and used durable goods. Journal of Law and Economics, 17(2), 381-401.

3. California Public Interest Research Group - Higher Education Project. (2004). Ripoff 101: How the current practices of the textbook industry drive up the cost of college textbooks. Los Angeles: Authors

4. Carbaugh, R., \& Ghosh, K. (2005). Are college textbooks fairly priced? Challenge, 48(5), 95-112.

5. Government Accountability Office. (2005). College textbooks: Enhanced offerings appear to drive recent price increases (GAO-05-806). Washington, DC: United States Government Accountability Office.

6. Iizuka, T. (2007). An empirical analysis of planned obsolescence. Journal of Economics \& Management Strategy, 16(1), 191-226.

7. Koch, J. (2006). An economic analysis of textbook pricing and textbook markets. Washington, DC: Advisory Committee on Student Financial Assistance, U.S. Department of Education

8. Miller, L. (1974). On killing off the market for used textbooks and the relationship between markets for new and secondhand goods. Journal of Political Economy, 82(3), 612-619.

9. Mui, Y. Q., \& Kinzie, S. (2008, August 20). Break on cost of textbooks unlikely before last bell, 2010. The Washington Post, p. A01.

10. NACS overview of Higher Education Opportunity Act textbook provisions [Pamphlet]. (2009). Oberlin, OH: National Association of College Stores.

11. State Public Interest Research Groups -Higher Education Project. (2005). Ripoff 101: How the publishing industry's practices needlessly drive up textbook costs. $2^{\text {nd }}$ Edition. Washington, DC: Authors

12. Student Public Interest Research Groups. (2007). Exposing the textbook industry: How publishers' pricing tactics drive up the cost of college textbooks. Boston, MA: Authors.

13. Swan, P. (1980). Alcoa: The influence of recycling on monopoly power. Journal of Political Economy, 88(1), 76-99.

14. Why PIRG is wrong: Myths and facts about college textbooks. [Pamphlet]. n.d. Washington, DC: Association of American Publishers, Inc. 
NOTES 